\title{
ANALISIS KERENTANAN PANTAI MENGGUNAKAN COASTAL VULNERABILITY INDEX (CVI) DI WILAYAH PESISIR TANJUNG PANDAN, KABUPATEN BELITUNG
}

\author{
Coastal Vulnerability Assessment Based on Coastal Vulnerability Index (CVI) at the Coastal Area of \\ Tanjung Pandan, Belitung District
}

Anditya Devi Rachmadianti, Frida Purwanti*), Nurul Latifah

Program Studi Manajemen Sumberdaya Perairan, Departemen Sumberdaya Akuatik

Fakultas Perikanan dan Ilmu Kelautan Universitas Diponegoro

Jl. Prof. Soedarto, SH, Tembalang, Semarang, Jawa Tengah - 50275, Telp/Fax. +6224 7474698

Email : andityadevi@gmail.com

\begin{abstract}
ABSTRAK
Wilayah pesisir Tanjung Pandan terdiri atas Kelurahan Air Saga, Tanjung Pendam dan Kampung Parit dan merupakan pusat ibukota Pulau Belitung. Tingginya kegiatan perikanan dan aktivitas manusia di wilayah ini menyebabkan perlunya kajian mengenai analisis kerentanan pantai guna melakukan upaya pencegahan kerusakan pantai dan pengelolaan wilayah pantai secara berkelanjutan. Tujuan dari penelitian ini adalah untuk mengetahui tingkat kerentanan dan lokasi kerentanan pantai yang paling tinggi serta variabel yang paling berpengaruh terhadap kerentanan pantai. Penelitian ini dilaksanakan pada bulan Mei 2018 dengan menganalisis variabel geomorfologi, erosi/akresi, kemiringan pantai, jarak tumbuhan dari pantai, pasang surut dan tinggi gelombang sesuai dengan indeks kerentanan pantai. Metode pengambilan data lapangan dilakukan melalui pengamatan secara langsung dengan pembagian sel pantai sebanyak 7 sel serta berdasarkan data sekunder. Hasil penelitian menunjukkan bahwa nilai CVI sel pantai 1-5 dan 7 tergolong kategori kerentanan rendah dengan nilai CVI berkisar antara 14,43 - 20,41, sedangkan sel pantai 6 tergolong kategori kerentanan menengah dengan nilai CVI 22,82. Lokasi kerentanan paling tinggi berada pada sel pantai 6 dengan kondisi geomorfologi pantai pasir serta paling dipengaruhi oleh variabel perubahan garis pantai akibat terjadinya peristiwa erosi.
\end{abstract}

Kata kunci: Kerentanan, CVI, Wilayah Pesisir, Tanjung Pandan, Belitung

\begin{abstract}
Tanjung Pandan Coastal Area consists of Air Saga, Pendam Cape and Kampung Parit region that are the centre of Belitung Island. The high activity of human and fisheries in the area cause the coastal vulnerability that need to be examined to prevent coastal damage and to manage the coastal area in a sustainable way. This study was conducted in May 2018 by analyzing geomorphology, shoreline erosion/accretion, coastal slope, plants distance from the coast, mean tide range and mean wave height based on coastal vulnerability index within direct observation at seven coastal cells and based on secondary data. The research showed that the CVI value on the $1^{\text {st }}-5^{\text {th }}$ cells and the $7^{\text {th }}$ cell categorized at low level with a range between 14,43-20,41, while the $6^{\text {th }}$ cell categorized at medium level with the CVI value 22,82. The highest vulnerability located on the $6^{\text {th }}$ cell with a sandy beach geomorphology and most affected by coastline changes variable due to the occurrence of erosion.
\end{abstract}

Keywords: Vulnerability, CVI, Coastal Area, Tanjung Pandan, Belitung

\section{*)Penulis Penanggungjawab}

\section{PENDAHULUAN}

Wilayah pesisir adalah daerah antara daratan dan lautan yang masih dipengaruhi oleh faktor darat dan laut. Diperkirakan hampir $60 \%$ dari total populasi penduduk Indonesia berada di wilayah pesisir (Baransano dan Jubhar, 2011). Semakin berkembang pesatnya wilayah pesisir mengakibatkan wilayah pesisir mengalami perubahan yang dinamis. Perubahan tersebut juga dipengaruhi oleh proses pasang surut, arus menyusur pantai dan gelombang yang mengakibatkan wilayah pantai mengalami kerentanan.

Kabupaten Belitung merupakan bagian dari wilayah Provinsi Kepulauan Bangka Belitung yang terletak di bagian timur Pulau Sumatera. Kabupaten ini memiliki lima kecamatan, salah satunya adalah Kecamatan Tanjung Pandan yang sekaligus menjadi ibukota dari Kabupaten Belitung. Kecamatan Tanjung Pandan terdiri dari 12 kelurahan dengan jumlah penduduk terbanyak dibandingkan dengan empat kecamatan lainnya. Bagian Barat Kecamatan Tanjung 
Pandan merupakan wilayah pesisir karena letaknya berbatasan langsung dengan perairan, yaitu Selat Gaspar, selat yang memisahkan Pulau Bangka dan Belitung. Garis pantai wilayah pesisir ini dilalui oleh tiga kelurahan, yaitu Kelurahan Air Saga, Tanjung Pendam dan Kampung Parit. Wilayah ini dipadati oleh pemukiman penduduk, perhotelan, restoran, serta dipadati dengan berbagai aktivitas, seperti adanya pariwisata pantai dan perikanan tangkap.

Pemilihan wilayah pesisir Tanjung Pandan didasarkan kepada letaknya yang dekat dengan jalur perdagangan dan pelayaran dari Pulau Belitung menuju pulau-pulau lain. Wilayah ini juga memiliki aktivitas yang cukup tinggi sebagai tempat pariwisata, pemukiman penduduk dan pemanfaatan sumberdaya alam serta menjadi salah satu lokasi strategis sebagai kawasan perhotelan di Pulau Belitung. Aktivitas-aktivitas didalamnya akan sangat mempengaruhi kondisi ekosistem pantai itu sendiri, bahkan dapat mengakibatkan perubahan. Salah satu wilayah pesisir Tanjung Pandan yang memiliki aktivitas yang tinggi adalah Pantai Tanjung Pendam. Menurut Husin et al. (2003), Pantai Tanjung Pendam memiliki substrat berpasir putih dan berlumpur. Pantai ini berlumpur sebagai akibat dari aktivitas penambangan timah di perairan tersebut. Mengingat pentingnya wilayah ini bagi masyarakat setempat, maka perlu dilaksanakan kajian mengenai analisis kerentanan wilayah pesisir Tanjung Pandan guna menyusun kebijakan yang tepat dalam pengelolaan wilayah pantai secara berkelanjutan.

Tujuan dari penelitian ini adalah untuk mengetahui tingkat kerentanan dan lokasi kerentanan pantai yang paling tinggi serta variabel yang paling berpengaruh terhadap kerentanan pantai.

\section{MATERI DAN METODE PENELITIAN}

Penelitian meliputi variabel fisik wilayah pesisir Tanjung Pandan, yang terdiri dari geomorfologi, erosi/akresi, kemiringan pantai, jarak tumbuhan dari pantai, rerata pasang surut dan tinggi gelombang. Alat dan bahan yang digunakan dalam penelitian adalah Global Positioning System (GPS), kayu sepanjang 2 meter, water pass, rol meter, kamera digital, alat tulis, perangkat lunak ArcGIS 10.3, Peta Rupa Bumi Indonesia (RBI), citra satelit Landsat OLI 8 dan Google Earth.

Metode dalam penelitian ini adalah metode deskriptif kuantitatif. Data yang diperoleh dari sampel penelitian dianalisis sesuai dengan metode yang digunakan kemudian diinterpretasikan. Gumilar (2013) mengartikan penelitan deskriptif dengan pendekatan kuantitatif sebagai penelitian yang dinyatakan dalam angka serta menjelaskannya dengan cara membandingkan dengan teori yang telah ada sebelumnya dan menganalisis data sesuai dengan variabel dalam penelitian. Sugiyono (2009) menyatakan bahwa penelitian kuantitatif sebagai metode penelitian yang digunakan untuk meneliti sampel tertentu secara random dengan pengumpulan data menggunakan instrumen penelitian serta analisis data yang bersifat kuantitatif untuk menguji hipotesis yang telah ditetapkan.

Lokasi penelitian terdiri atas Kelurahan Air Saga, Tanjung Pendam dan Kampung Parit yang dibagi menjadi tujuh sel dengan panjang sel yang bervariasi tergantung kepada kondisi geomorfologi garis pantai, seperti kawasan mangrove, restoran, perhotelan, pemukiman penduduk serta pantai wisata. Sel 1-3 berada pada Kelurahan Air Saga, sel 4-6 berada pada Kelurahan Tanjung Pendam dan sel 7 berada pada Kelurahan Kampung Parit. Peta lokasi penelitian tersaji dalam Gambar 1.

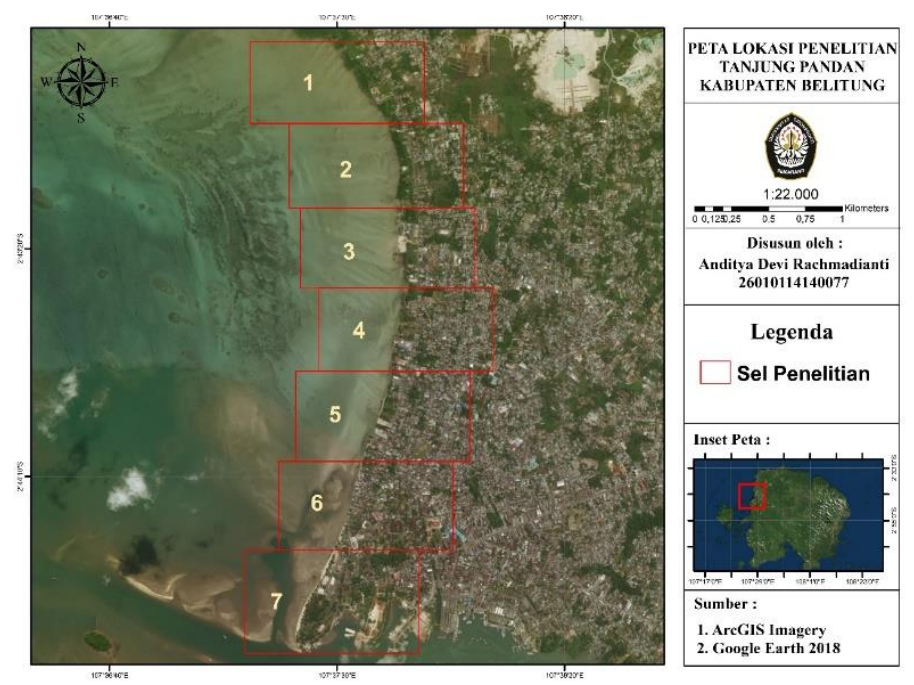

Gambar 1. Peta Lokasi Penelitian

Data primer yang diperoleh secara langsung di lapangan terdiri dari pengukuran geomorfologi, kemiringan pantai dan jarak tumbuhan dari pantai, sedangkan data sekunder berupa data gelombang, pasang surut dan perubahan garis pantai (erosi/akresi) yang diolah dari citra satelit.

\section{Analisa Data}

Variabel yang digunakan dalam menentukan CVI pada pantai menggunakan enam variabel dengan pembobotan kerentanan pantai kategori sangat rendah hingga sangat tinggi yang tersaji dalam Tabel 1 . 
Tabel 1. Kategori Penilaian Coastal Vulnerability Index

\begin{tabular}{|c|c|c|c|c|c|c|}
\hline No. & Variabel & $\begin{array}{l}\text { Sangat } \\
\text { Rendah }\end{array}$ & Rendah & Menengah & Tinggi & $\begin{array}{l}\text { Sangat } \\
\text { Tinggi }\end{array}$ \\
\hline & & 1 & 2 & 3 & 4 & 5 \\
\hline $\mathrm{a}$ & Geomorfologi & $\begin{array}{c}\text { Pantai } \\
\text { bertebing } \\
\text { berbatu }\end{array}$ & $\begin{array}{c}\text { Bertebing } \\
\text { menengah, } \\
\text { berbatu }\end{array}$ & $\begin{array}{l}\text { Bertebing } \\
\text { rendah, } \\
\text { berbatu, } \\
\text { dataran } \\
\text { aluvial }\end{array}$ & $\begin{array}{l}\text { Pantai } \\
\text { berbatu } \\
\text { kerikil, } \\
\text { estuari, } \\
\text { lagoon }\end{array}$ & $\begin{array}{c}\text { Pantai pasir, } \\
\text { rawa-rawa } \\
\text { pantai, delta, } \\
\text { mangrove, } \\
\text { terumbu } \\
\text { karang }\end{array}$ \\
\hline $\mathrm{b}$ & $\begin{array}{l}\text { Erosi/akresi atau } \\
\text { perubahan garis } \\
\text { pantai (m/tahun) }\end{array}$ & $>2,0$ & $1,0-2,0$ & $(-1,0)-1,0$ & $(-2,0)-(-1,0)$ & $<(-2,0)$ \\
\hline $\mathrm{c}$ & $\begin{array}{l}\text { Kemiringan } \\
\text { pantai }(\%)\end{array}$ & $>1,20$ & $1,20-0,90$ & $0,90-0,60$ & $0,60-0,30$ & $<0,30$ \\
\hline d & $\begin{array}{l}\text { Jarak tumbuhan } \\
\text { dari pantai }(\mathrm{m})\end{array}$ & $>600$ & $200-600$ & $100-200$ & $100-50$ & $<50$ \\
\hline $\mathrm{e}$ & $\begin{array}{l}\text { Tinggi gelombang } \\
\text { rerata }(\mathrm{m})\end{array}$ & $<0,55$ & $0,55-0,85$ & $0,85-1,05$ & $1,05-1,25$ & $>1,25$ \\
\hline $\mathrm{f}$ & $\begin{array}{l}\text { Kisaran pasang } \\
\text { rerata }(\mathrm{m})\end{array}$ & $>6,0$ & $4,0-6,0$ & $2,0-4,0$ & $1,0-2,0$ & $<1,0$ \\
\hline
\end{tabular}

Sumber: Modifikasi Hammar-Klose et al. (2003); Handartoputra et al. (2015)

Kerentanan pantai dari setiap variabel dihitung dengan metode CVI yang ditetapkan oleh USGS (1999) dalam Handartoputra et al. (2015), nilai variabel terdiri atas lima kelas $(1=$ sangat rendah, $2=$ rendah, $3=$ moderat, $4=$ tinggi, 5 = sangat tinggi), selanjutnya indeks kerentanan dinilai berdasarkan hasil perhitungan nilai tiap masing-masing variabel melalui persamaan (1):

$$
\mathrm{CVI}=\sqrt{\frac{a x b x c x d x e x f}{6}}
$$

dimana CVI adalah nilai Indeks Kerentanan Pantai, sedangkan $\mathrm{a}, \mathrm{b}, \mathrm{c}, \mathrm{d}$, e dan $\mathrm{f}$ adalah variabel berturut-turut: geomorfologi, erosi/akresi atau perubahan garis pantai, kemiringan pantai, jarak tumbuhan dari pantai, rerata tinggi gelombang dan rerata kisaran pasang surut. Penentuan kategori kerentanan berdasarkan nilai CVI tersaji dalam Tabel 2. Tabel 2. Penentuan Kategori Kerentanan dari Nilai CVI

\begin{tabular}{cc}
\hline Nilai CVI & Kategori Kerentanan \\
\hline$<20,5$ & Rendah \\
$20,5-25,5$ & Menengah \\
$25,6-29,0$ & Tinggi \\
$>29,0$ & Sangat Tinggi \\
\hline
\end{tabular}

Sumber: Hammar-Klose et al. (2003)

Nilai CVI serta kategori kerentanan yang telah didapatkan dari masing-masing sel pantai kemudian dibandingkan hasilnya berdasarkan nilai dari masing-masing variabel kerentanan untuk didapatkan lokasi sel pantai yang memiliki nilai kerentanan paling tinggi serta variabel kerentanan yang tergolong kedalam kategori paling tinggi dan paling berpengaruh terhadap nilai kerentanan di sel pantai tersebut.

\section{HASIL DAN PEMBAHASAN}

Secara geografis, Kabupaten Belitung terletak antara $107^{\circ} 08^{\prime}$ BT sampai $107^{\circ} 58^{\prime}$ BT dan $2^{\circ} 30^{\prime}$ LS sampai $3^{\circ} 15^{\prime}$ LS dengan luas seluruhnya 2.293,69 $\mathrm{km}^{2}$. Kabupaten ini berbatasan dengan Laut Cina Selatan di sebelah utara, sebelah timur berbatasan dengan Kabupaten Belitung Timur, sebelah selatan berbatasan dengan Laut Jawa dan sebelah barat berbatasan dengan Selat Gaspar. Letak geografis yang strategis ini berada dekat dengan jalur perdagangan dan pelayaran internasional. Pulau Belitung memiliki akses menuju Pulau Jawa, Pulau Sumatera, Pulau Kalimantan dan Singapura. Hal ini menjadikan sektor perhubungan sebagai salah satu keunggulan dari Belitung, selain sektor pariwisata. Belitung juga kaya akan potensi perikanan dan kelautan. Kegiatan perikanan tangkap, budidaya perikanan dan sumberdaya tambangnya sudah semakin berkembang.

Kabupaten Belitung memiliki jumlah penduduk sebanyak 186.155 jiwa pada tahun 2018. Penduduk Kabupaten Belitung menjunjung tinggi kerukunan beragama dan memiliki tempat peribadatan agama sebanyak 133 masjid, 7 gereja Protestan, 3 gereja Katolik, 4 pura dan 6 vihara. Daerah yang paling tinggi di Kabupaten Belitung hanya mempunyai ketinggian kurang lebih 500 meter dari atas permukaan laut dengan puncak tertinggi berada di daerah Gunung Tajam, sedangkan daerah hilir terdiri dari beberapa Daerah Aliran Sungai (DAS). Kondisi topografi Pulau Belitung pada umumnya bergelombang dan berbukit-bukit yang telah membentuk pola aliran sungai di daerah ini menjadi pola sentrifugal, dimana sungai-sungai yang ada berhulu di daerah pegunungan dan mengalir ke daerah pantai. Keadaan tanah di kabupaten ini umumnya didominasi oleh kuarsa dan pasir, batuan aluvial dan batuan granit (BPS Kabupaten Belitung, 2016). 


\section{Geomorfologi}

Geomorfologi pantai berhubungan dengan kenampakan wilayah pesisir. Perubahan bentuk lahan pesisir menghasilkan suatu bentukan di permukaan bumi yang memiliki karakteristik fisik dan visual yang berbeda-beda (Dhiauddin, 2017). Daerah mangrove membentang di daerah Utara Wilayah Pesisir Tanjung Pandan, yaitu Kelurahan Air Saga (sel 1 dan 2). Daerah rawa-rawa pantai yang ditumbuhi mangrove berada di Kelurahan Air Saga (sel 3) dan Kelurahan Tanjung Pendam (sel 4). Terdapat pula pantai pasir yang ditumbuhi mangrove pada sel 5 dan pantai pasir pada sel 6 yang berada di Kelurahan Tanjung Pendam. Daerah pantai pasir yang membentang di daerah Selatan Wilayah Pesisir Tanjung Pandan berada pada Kelurahan Kampung Parit (sel 7). Peta skor kerentanan pantai variabel geomorfologi tersaji dalam Gambar 2.

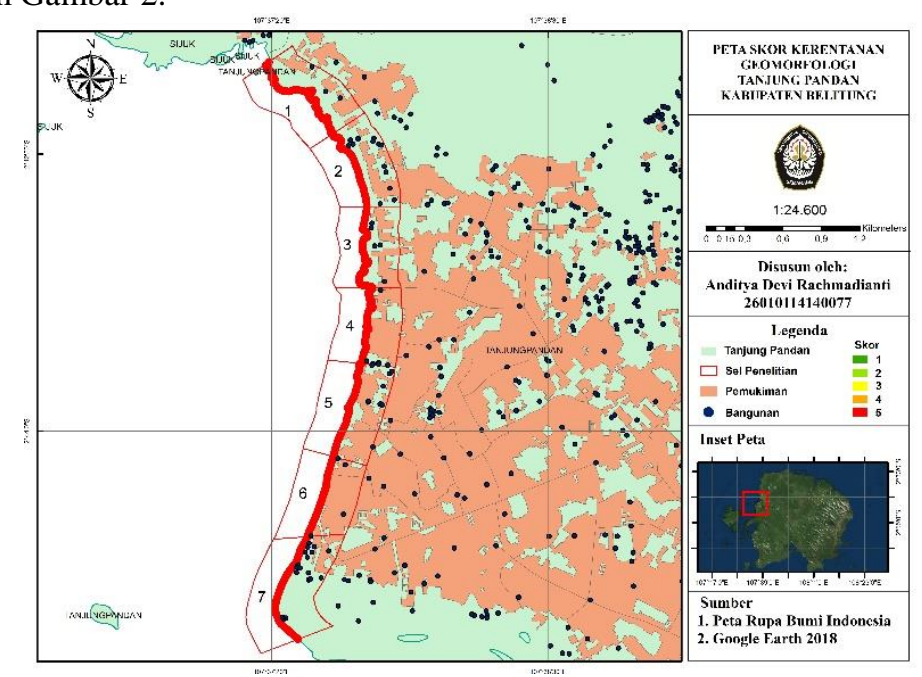

Gambar 2. Peta Skor Kerentanan Pantai Tanjung Pandan dengan Variabel Geomorfologi

Kondisi sel 1 dan 2 adalah ekosistem mangrove di sepanjang garis pantainya, sedangkan sel 3, 4 dan 5 adalah rawa-rawa pantai dan pantai berpasir yang ditumbuhi mangrove. Ekosistem mangrove pada sel pantai ini telah mengalami banyak kerusakan yang mempengaruhi daya kekuatan mangrove tersebut dalam menghalangi datangnya gelombang. Kondisi sel 6 adalah pantai pasir yang terdapat beberapa pemukiman penduduk dan sel 7 adalah kawasan wisata Pantai Tanjung Pendam dengan kondisi pantai pasir. Novianti dan Oda (2016) menyatakan Pantai Tanjung Pendam merupakan satu-satunya pantai yang berada di Kota Tanjung Pandan serta berpotensi dalam hal wisata alam, budaya dan buatan yang layak untuk dikembangkan sebagai kawasan wisata.

\section{Perubahan Garis Pantai}

Perubahan garis pantai adalah suatu proses yang terjadi secara terus menerus baik berupa erosi maupun akresi. Perubahan garis pantai terjadi karena adanya angkutan sedimen dari daratan maupun laut serta diakibatkan pengikisan oleh air laut. Laju perubahan garis pantai diekspresikan sebagai jarak dari suatu posisi garis pantai mengalami perpindahan setiap tahun (Sulma, 2012). Hasil analisis perubahan garis pantai pada tahun $2008-2018$ sebagian besar mengalami akresi. Wilayah pesisir ini mengalami erosi pada Kelurahan Air Saga (sel 2 dan 3), Kelurahan Tanjung Pendam (sel 4-6), serta Kelurahan Kampung Parit (sel 7). Peristiwa akresi hanya terjadi di Kelurahan Air Saga (sel 1-3) dan Kelurahan Tanjung Pendam (sel 4 dan 5). Peta erosi/akresi di Tanjung Pandan tersaji dalam Gambar 3.

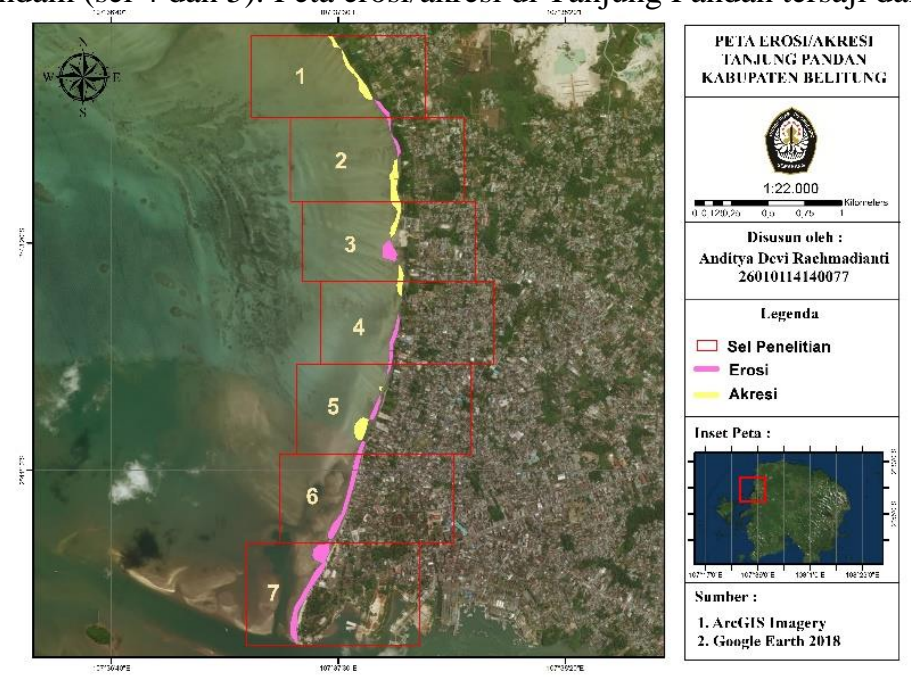

Gambar 3. Perubahan Garis Pantai

\footnotetext{
${ }^{\circledR}$ Copyright by Management of Aquatic Resources (MAQUARES)
} 
Peta skor kerentanan pantai variabel perubahan garis pantai tersaji dalam Gambar 4.

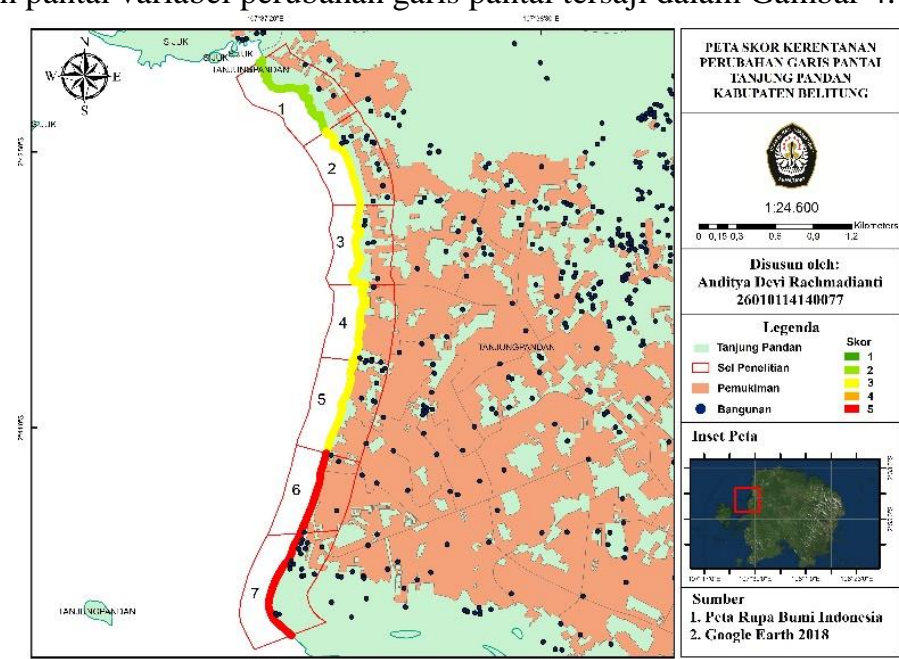

Gambar 4. Peta Skor Kerentanan Pantai Tanjung Pandan dengan Variabel Perubahan Garis Pantai

Ekosistem mangrove pada sel 1 mengalami penambahan lahan (akresi) yang kemungkinan disebabkan oleh adanya peristiwa sedimentasi dari daratan yang mengendap di pantai dikarenakan letaknya yang berada dekat dengan muara Sungai Kubu yang menjadi pemisah antara Kecamatan Tanjung Pandan dengan Kecamatan Sijuk. Parman (2010) menyatakan bahwa akresi yang mengubah garis pantai disebabkan oleh banyaknya sungai yang bermuara di laut sekitar. Air dari aliran sungai membawa sedimen darat dan mengalami pengendapan di daerah pantai. Istiqomah et al. (2016) juga menyatakan bahwa akresi adalah perubahan garis pantai dikarenakan sedimentasi dari daratan atau sungai menuju arah laut. Proses akresi pantai biasanya terjadi di perairan yang banyak memiliki muara sungai dan gelombang laut yang kecil serta wilayah yang jarang mengalami badai.

Sel pantai 6 dan 7 mengalami erosi yang kemungkinan disebabkan oleh gerakan pasang surut dan gelombang laut serta sedikitnya mangrove yang tumbuh di kedua sel tersebut sehingga wilayah daratan kurang terlindungi dari gelombang. Menurut Damaywanti (2013), peristiwa erosi diakibatkan oleh arus dan pasang surut. Adanya gaya hidrodinamika gelombang juga dapat mengakibatkan erosi di daerah pantai.

\section{Kemiringan Pantai}

Kemiringan pantai dapat mempengaruhi penumpukan sedimen (akresi) sehingga menyebabkan ketidak stabilan pada wilayah pantai. Letak suatu kawasan di daerah pesisir yang semakin tinggi akan meningkatkan keamanan daerah tersebut dari bahaya genangan akibat kenaikan muka air laut (Syahrir et al., 2010). Kelurahan Air Saga, Tanjung Pendam dan Kampung Parit (sel 1 - 7) memiliki tipe pantai yang landai dengan nilai kemiringan pantai kurang dari $0,30 \%$ sehingga tergolong kedalam kategori kerentanan sangat tinggi. Peta skor kerentanan pantai variabel kemiringan pantai tersaji dalam Gambar 5.

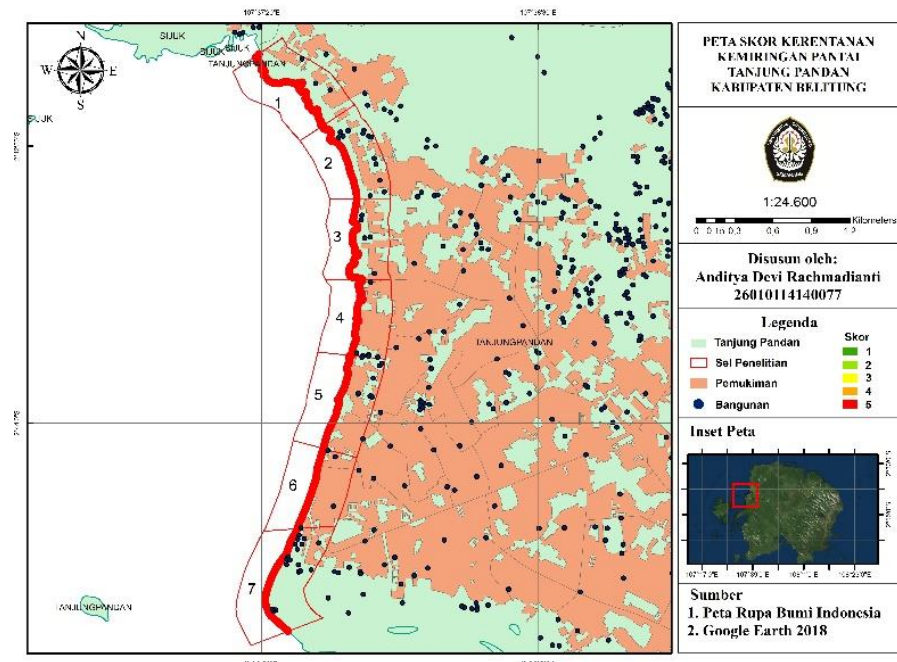

Gambar 5. Peta Skor Kerentanan Pantai Tanjung Pandan dengan Variabel Kemiringan Pantai

Wilayah Pesisir Tanjung Pandan memiliki pantai yang landai dengan kisaran kemiringan pantai sebesar 0,09\% $0,27 \%$ yang tergolong kategori kerentanan sangat tinggi. Pantai landai akan lebih rentan dibandingkan dengan pantai yang bertebing curam dan berbatu karena lebih kuat menahan gelombang dari laut serta erosi. Keterbukaan pantai terhadap hempasan karena tidak terdapatnya penghalang (barrier) akan membuat daratan pantai lebih mudah tergerus gelombang.

${ }^{\odot}$ Copyright by Management of Aquatic Resources (MAQUARES) 


\section{Jarak Tumbuhan dari Pantai}

Tumbuhan atau vegetasi pantai umumnya memiliki akar yang panjang dan kokoh untuk menahan substrat dan sedimen yang terhempas oleh gelombang. Kerapatan vegetasi dari pantai ke arah darat, topografi pantai, karakteristik substrat serta kondisi ekosistem yang berada disekitar vegetasi tersebut akan sangat menentukan efektifitas vegetasi pantai dalam meredam gelombang (Desai, 2000). Kelurahan Air Saga dan Tanjung Pendam (sel 1 - 6) memiliki nilai kurang dari $50 \mathrm{~m}$ sehingga tergolong kedalam kategori kerentanan sangat tinggi. Wilayah pantai pada Kelurahan Kampung Parit (sel 7) memiliki jarak tumbuhan dari pantai terjauh dan tergolong kategori kerentanan tinggi. Peta skor kerentanan pantai variabel jarak tumbuhan dari pantai tersaji dalam Gambar 6.

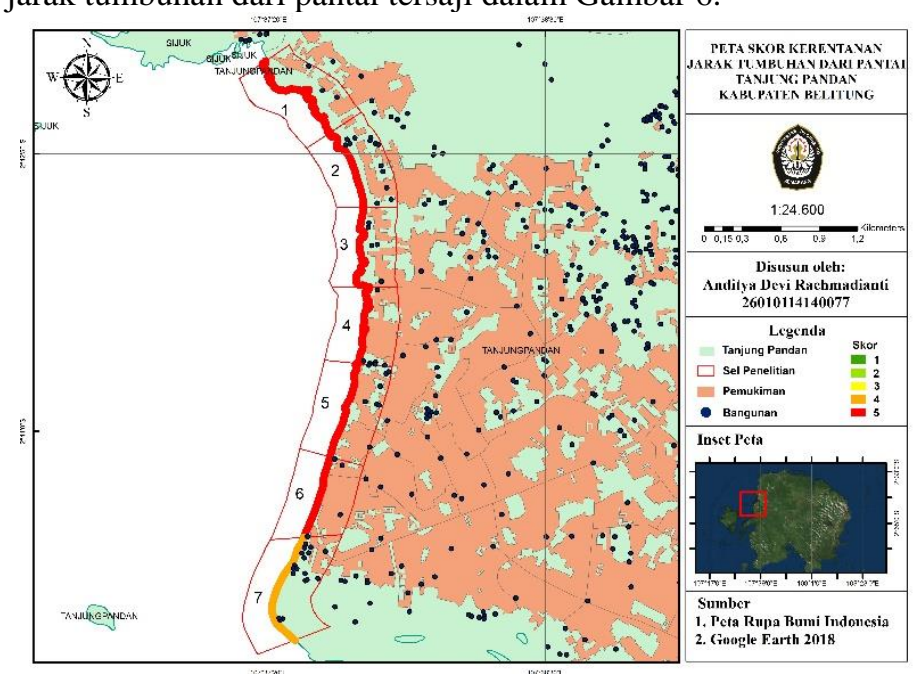

Gambar 6. Peta Skor Kerentanan Pantai Tanjung Pandan dengan Variabel Jarak Tumbuhan dari Pantai

Vegetasi mangrove yang tumbuh di sepanjang garis pantai Tanjung Pandan sangat berguna untuk menahan datangnya gelombang, namun, terjadinya erosi dan pembangunan kawasan hotel di tepi pantai mengakibatkan rusaknya habitat mangrove di sekitar pantai. Desai (2000) menyatakan bahwa vegetasi pantai berperan penting dalam mencegah terjadinya erosi. Hilangnya vegetasi ini akan memberikan pengaruh bagi ekosistem di sekitarnya. Kerapatan vegetasi dan topografi pantai akan menentukan besarnya efektifitas vegetasi pantai dalam meredam gelombang.

\section{Pasang Surut}

Pasang surut merupakan fenomena pergerakan naik turunnya muka air laut secara berkala akibat adanya gaya tarik benda-benda angkasa terutama matahari dan bulan terhadap massa air di bumi. Rentang pasang surut berhubungan dengan arus pasang surut yang berpotensi menyebabkan erosi wilayah pesisir. Wilayah dengan rentang pasang surut yang panjang akan meningkatkan jangkauan pengaruh dari kenaikan muka air laut ke daratan serta mampu menimbulkan erosi pantai (Tiraska, 2017). Nilai rerata pasang surut Wilayah Pesisir Tanjung Pandan tahun $2010-$ 2018 menunjukkan bahwa wilayah ini mengalami peristiwa pasang surut yang rendah dengan nilai kurang dari $1 \mathrm{~m}$ tiap tahunnya sehingga tergolong kedalam kerentanan sangat tinggi. Peta skor kerentanan pantai variabel pasang surut tersaji dalam Gambar 7.

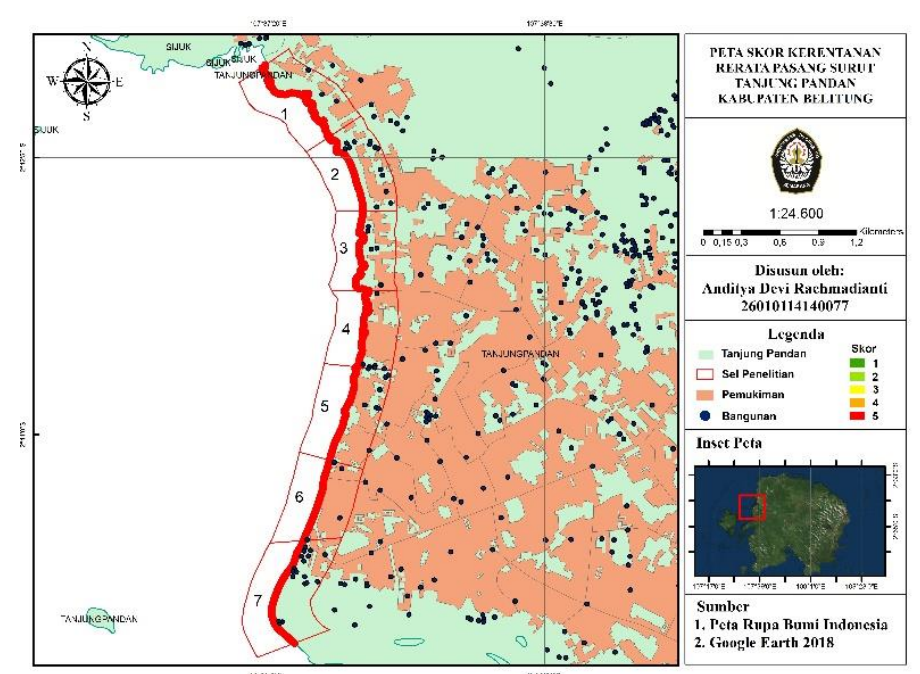

Gambar 7. Peta Skor Kerentanan Pantai Tanjung Pandan dengan Variabel Pasang Surut

Besarnya nilai pasang surut berpengaruh terhadap perubahan garis pantai di wilayah pesisir karena peristiwa pasang surut secara terus-menerus dapat mengubah permukaan dasar laut hingga menuju ke pantai. Menurut Qhomariyah dan Yuwono (2016), gaya pasang surut mempengaruhi peristiwa abrasi dan sedimentasi. Pada saat terjadi

\footnotetext{
${ }^{\odot}$ Copyright by Management of Aquatic Resources (MAQUARES)
} 
pasang, material yang mengendap di dasar perairan akan terbawa oleh arus pasang tersebut. Peristiwa ini dinamakan sedimentasi. Jumlah sedimentasi di setiap tempat bervariasi dikarenakan adanya perbedaan pengaruh pasang surut yang terjadi di perairan tersebut dan respon yang dilakukan oleh tempat terbentuknya sedimentasi, disamping pengaruh yang disebabkan oleh ombak dan angin.

\section{Gelombang}

Gelombang adalah variabel utama dalam proses erosi atau sedimentasi. Besar suatu gelombang tergantung kepada besarnya energi yang ditentukan oleh tinggi gelombang sebelum pecah, kemudian dihempaskan oleh gelombang ke pantai. Besar kecilnya nilai gelombang dapat berpengaruh terhadap kondisi geomorfologi dan perubahan garis pantai di wilayah tersebut. Selain itu, ketinggian gelombang berhubungan dengan bahaya penggenangan air laut dan transport sedimen di wilayah pesisir (Dhiauddin, 2017). Nilai rerata tinggi gelombang signifikan Wilayah Pesisir Tanjung Pandan tahun 2009 - 2016 menunjukkan bahwa Kelurahan Air Saga, Tanjung Pendam dan Kampung Parit (sel 1-7) memiliki nilai gelombang sebesar kurang dari 0,55 m sehingga tergolong kedalam kerentanan sangat rendah, meskipun pada tahun 2011, 2014 dan 2015 nilai tinggi gelombang signifikan lebih dari 0,55 m (tergolong kerentanan rendah). Peta skor kerentanan pantai variabel tinggi gelombang tersaji dalam Gambar 8.

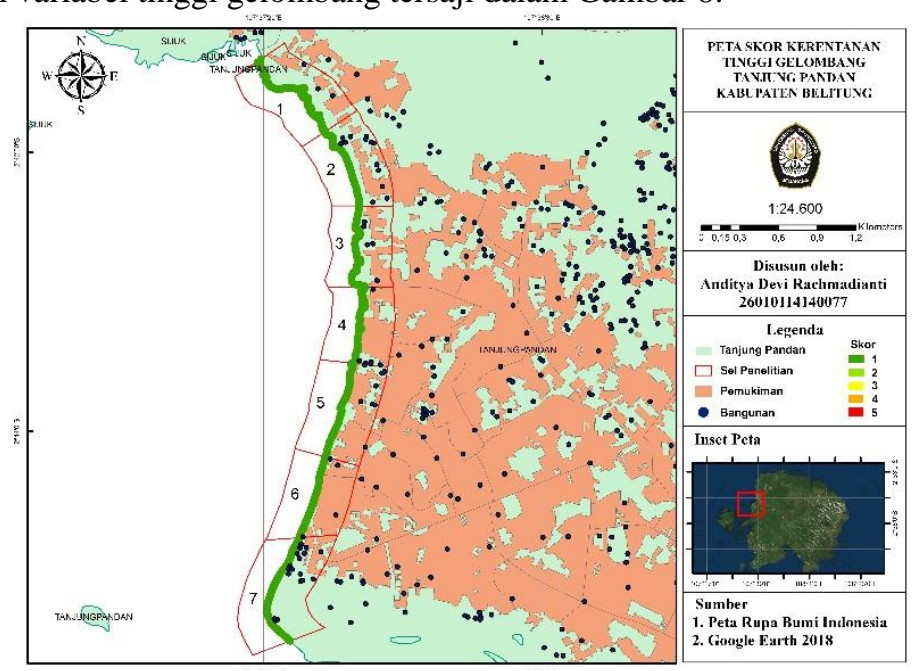

Gambar 8. Peta Skor Kerentanan Pantai Tanjung Pandan dengan Variabel Tinggi Gelombang

Nilai gelombang berpengaruh terhadap erosi/akresi yang terjadi di wilayah pesisir Tanjung Pandan. Pada musim tertentu, gelombang yang besar juga dapat menyebabkan terjadinya kerusakan pada vegetasi yang ada di sepanjang pesisir, seperti mangrove. Hal ini diperkuat oleh pernyataan Dhiauddin (2017) bahwa parameter utama dalam proses erosi atau sedimentasi dapat dilihat melalui besarnya gelombang. Besar kecilnya nilai gelombang di suatu wilayah pesisir dapat mempengaruhi kondisi geomorfologi dan perubahan garis pantai serta transpor sedimen di wilayah tersebut.

\section{Tingkat Kerentanan Pantai}

Tingkat kerentanan berdasarkan nilai CVI pada masing-masing sel pantai tersaji dalam Tabel 3.

Tabel 3. Nilai Skor CVI di Wilayah Pesisir Tanjung Pandan

\begin{tabular}{ccccccccc}
\hline $\begin{array}{c}\text { Sel } \\
\text { Pantai }\end{array}$ & Geomorfologi & $\begin{array}{c}\text { Erosi/ } \\
\text { Akresi } \\
\text { Pantai }\end{array}$ & $\begin{array}{c}\text { Kemiringan } \\
\text { Pantai }\end{array}$ & $\begin{array}{c}\text { Jarak } \\
\text { Tumbuhan } \\
\text { dari } \\
\text { Pantai }\end{array}$ & $\begin{array}{c}\text { Pasang } \\
\text { Surut }\end{array}$ & Gelombang & CVI & $\begin{array}{c}\text { Kategori } \\
\text { Kerentanan }\end{array}$ \\
\hline 1 & 5 & 2 & 5 & 5 & 5 & 1 & 14,43 & Rendah \\
2 & 5 & 3 & 5 & 5 & 5 & 1 & 17,67 & Rendah \\
3 & 5 & 3 & 5 & 5 & 5 & 1 & 17,67 & Rendah \\
4 & 5 & 3 & 5 & 5 & 5 & 1 & 17,67 & Rendah \\
5 & 5 & 3 & 5 & 5 & 5 & 1 & 17,67 & Rendah \\
6 & 5 & 5 & 5 & 5 & 5 & 1 & 22,82 & Menengah \\
7 & 5 & 5 & 5 & 4 & 5 & 1 & 20,41 & Rendah \\
\hline
\end{tabular}

Peta skor kategori kerentanan di Wilayah Pesisir Tanjung Pandan tersaji dalam Gambar 9. 


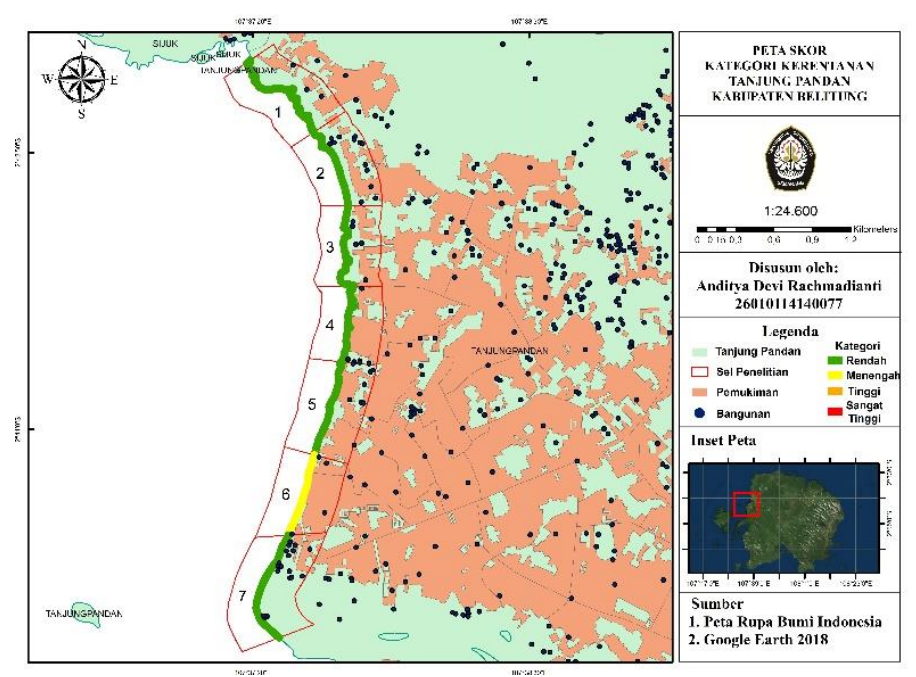

Gambar 9. Peta Skor Kategori Kerentanan Tanjung Pandan

Lokasi sel pantai yang memiliki nilai kerentanan tertinggi adalah sel 6. Variabel dengan nilai kerentanan tertinggi pada sel 6 adalah variabel geomorfologi, perubahan garis pantai, kemiringan pantai, jarak tumbuhan dari pantai, dan pasang surut. Kelima variabel tersebut berpengaruh terhadap nilai CVI di sel 6, akan tetapi jika dibandingkan dengan masing-masing variabel di enam sel pantai lainnya, variabel yang paling tinggi adalah perubahan garis pantai dan jarak tumbuhan dari pantai.

Sel 6 merupakan wilayah pantai pasir yang terdapat beberapa pemukiman penduduk yang sebagian besar bermata pencaharian sebagai nelayan. Daerah bibir pantai sel ini telah dibangun tembok batu sebagai penahan ombak agar ombak tidak menghempas rumah penduduk secara langsung. Sel ini juga memiliki kawasan lahan kosong yang sedang dalam tahap pembangunan sehingga mempengaruhi sedimentasi di sekitar daerah yang sedang dibangun. Pembangunan ini juga menyebabkan keruhnya perairan di sekitar sel pantai.

Variabel yang tergolong kategori kerentanan sangat tinggi pada sel 6 adalah seluruh variabel indeks kerentanan pantai, kecuali nilai tinggi gelombang yang tergolong kerentanan sangat rendah. Variabel perubahan garis pantai di sel 6 memiliki skor kerentanan sangat tinggi karena terjadi erosi dalam kurun waktu 10 tahun terakhir. Hal ini kemungkinan disebabkan karena sedikitnya mangrove yang hidup pada sel ini.

\section{KESIMPULAN}

Tingkat kerentanan di wilayah pesisir Tanjung Pandan berdasarkan indeks kerentanan pantai tergolong kedalam kategori kerentanan rendah (sel 1-5 dan 7) serta menengah (sel 6) dengan kisaran nilai CVI sebesar 14,43 - 22,82. Lokasi kerentanan dari ketujuh sel yang paling tinggi berada pada sel pantai 6 dengan kondisi geomorfologi pantai pasir serta dipengaruhi oleh variabel perubahan garis pantai dikarenakan terjadinya peristiwa erosi di sel pantai tersebut.

\section{UCAPAN TERIMA KASIH}

Penulis mengucapkan terima kasih kepada Dr. Ir. Haeruddin, M.Si dan Dr. Ir. Max Rudolf Muskananfola atas masukan dan saran dalam pembuatan jurnal ini.

\section{DAFTAR PUSTAKA}

Baransano, H. K. dan J. C. Mangimbulude. 2011. Eksploitasi dan Konservasi Sumberdaya Hayati Laut dan Pesisir di Indonesia. Jurnal Biologi Papua, 3(1): 39-45.

BPS Kabupaten Belitung. 2016. Kabupaten Belitung dalam Angka. Badan Pusat Statistik Kabupaten Belitung. 312 hlm.

Damaywanti, K. 2013. Dampak Abrasi Pantai terhadap Lingkungan Sosial (Studi Kasus di Desa Bedono, Sayung Demak). Prosiding Seminar Nasional Pengelolaan Sumberdaya Alam dan Lingkungan, 363-367.

Desai, K. N. 2000. Dune Vegetation: Need for Reappraisal. Coastin. A Coastal Policy Research Newsletter (3).

Dhiauddin, R., W. A. Gemilang, U. J. Wisha, G. A. Rahmawan dan G. Kusumah. 2017. Pemetaan Kerentanan Pesisir Pulau Simeulue dengan Metode CVI (Coastal Vulnerability Index). Jurnal EnviroScienteae, 13(2): 157-170.

Gumilar, G. R. 2013. Kontribusi Pelatihan Kewirausahaan terhadap Motivasi Berwirausaha bagi Peserta Pelatihan Persiapan Purna Bakti di Lembaga LP2ES Bandung. [Skripsi]. Fakultas Ilmu Pendidikan, Universitas Pendidikan Indonesia, Bandung.

Hammar-Klose, E. S., E. A. Pendleton, E. R. Thieler dan S. J. Williams. 2003. Coastal Vulnerability Assessment of Cape Cod National Seashore (CACO) to Sea-Level Rise. U.S. Geological Survey, Open File Report 02-233 http://pubs.usgs.gov/of/2002/of02-233/ 
Handartoputra, A., F. Purwanti dan B. Hendrarto. 2015. Penilaian Kerentanan Pantai di Sendang Biru Kabupaten Malang terhadap Variabel Oceanografi berdasarkan Metode CVI (Coastal Vulnerability Index). Jurnal Maquares, 4(1): 91-97.

Husin, H., S. B. Silalahi, H. Kartono dan T. L. Indra. 2003. Wilayah Potensial Wisata Bahari di Kabupaten Belitung. [Tesis]. Program Magister Ilmu Geografi, Universitas Indonesia, Depok.

Istiqomah, F., B. Sasmito dan F. J. Amarrohman. 2016. Pemantauan Perubahan Garis Pantai menggunakan Aplikasi Digital Shoreline Analysis System (DSAS) Studi Kasus: Pesisir Kabupaten Demak. Jurnal Geodesi Undip, 5(1): 78-89.

Novianti, S. dan O. I. B. Hariyanto. 2016. Pengembangan Atraksi Wisata Pantai Tanjung Pendam sebagai Daya Tarik Wisata. Jurnal Pariwisata, 3(1).

Parman, S. 2010. Deteksi Perubahan Garis Pantai melalui Citra Penginderaan Jauh di Pantai Utara Semarang Demak. Jurnal Geografi, 7(1): 30-38.

Qhomariyah, L. dan Yuwono. 2016. Analisa Hubungan Antara Pasang Surut Air Laut dengan Sedimentasi yang Terbentuk (Studi Kasus: Dermaga Pelabuhan Petikemas Surabaya). Jurnal Teknik ITS, 5(1): 1-3.

Sugiyono. 2009. Metode Penelitian Pendidikan. Alfabeta. Bandung.

Sulma, S. 2012. Kerentanan Pesisir terhadap Kenaikan Muka Air Laut, Studi Kasus: Surabaya dan Daerah Sekitarnya. [Tesis]. Universitas Indonesia, Depok.

Syahrir, E. W., Sakka dan S. Arif. 2010. Analisis Kerentanan Pantai di Kabupaten Takalar. Jurnal Geofisika. Fakultas Matematika dan Ilmu Pengetahuan Alam. Universitas Hasanuddin. Makassar.

Tiraska, A. 2017. Analisis Kerentanan Wilayah Pesisir Palabuhanratu terhadap Kenaikan Muka Laut menggunakan Pendekatan SIG. Jurnal Ilmu Kelautan dan Teknologi. 